\title{
PERANCANGAN ENTERPRISE ARCHITECTURE FUNGSI PEMASARAN DAN CRM PADA INDUSTRI PARIWISATA DI PERUM PERHUTANI UNIT III DENGAN MENGGUNAKAN FRAMEWORK TOGAF
}

\author{
${ }^{1}$ Fitri Febriana Purba, ${ }^{2}$ Rd. Rohmat Saedudin, ${ }^{3}$ Basuki Rahmad \\ 1,2,3 Program Studi Sistem Informasi, Fakultas Rekayasa Industri, Telkom University \\ ${ }^{1}$ fitri.febriana28@gmail.com, ${ }^{2}$ rdrohmat@telkomuniversity.ac.id, ${ }^{3}$ azkaku@gmail.com
}

\begin{abstract}
Abstrak-Perum Perhutani Unit III merupakan salah satu penyedia sektor pariwisata alam yang mengelola sumberdaya hutan di kawasan Jawa Barat dan Banten. Perkembangan industri pariwisata menuntut Perum Perhutani Unit III untuk memilih strategi pemasaran terbaik dan mengelola hubungan dengan pelanggan untuk menghasilkan keunggulan wisata yang kompetitif. Pemasaran destinasi wisata diharapkan mampu mengembangkan pariwisata di wilayah tersebut serta memastikan kelestarian sumber daya destinasi wisata melalui kegiatan promosi yang tepat sasaran. Sedangkan manajemen hubungan pelanggan (CRM) berfokus pada bagaimana menciptakan komunikasi yang baik dengan pelanggan untuk tetap setia pada produk yang ditawarkan dalam jangka panjang.Berdasarkan pada permasalahan diatas, Perum Perhutani Unit III membutuhkan perancangan enteprise architecture yang dapat menunjang kegiatan pemasaran dan manajemen hubungan pelanggan melalui pemanfaatan teknologi informasi. Enterprise architecture juga dapat membantu menyelaraskan strategi kompetetif Perum Perhutani III dengan teknologi informasi. Perancangan enterprise architecture membutuhkan sebuah kerangka kerja (framework) yang mengidentifikasi ruang lingkup arsitektur dan menetapkan hubungan antara area arsitektur. Perancangan enterprise architecture pada penelitian ini menggunakan framework TOGAF yang mempunyai beberapa fase, diantaranya preliminary phase, architecture vision, business architecture, information system architecture, dan technology architecture. Hasil perancangan ini berupa model bisnis target dan artifak pada setia tahapan.
\end{abstract}

Kata Kunci: Enterprise Architecture, TOGAF, Pariwisata, Perum Perhutani, Pemasaran, Manajemen Hubungan Pelanggan

\section{PENDAHULUAN}

Perkembangan potensi pasar wisata menuntut Perum Perhutani Unit III untuk memilih strategi pemasaran terbaik dan mengelola hubungan dengan pelanggan untuk menghasilkan keunggulan wisata yang kompetitif. Pemasaran destinasi wisata dianggap sebagai alat manajemen pariwisata strategis dalam memberikan keseimbangan antara tujuan stakeholder untuk pengembangan pariwisata di wilayah tersebut serta memastikan kelestarian sumber daya destinasi wisata. Pemasaran detinasi wisata berfokus pada penciptaan citra dan promosi bertujuan untuk mencapai pertumbuhan kunjungan domestik dan internasional [1]. Sedangkan manajemen hubungan pelanggan (CRM) berfokus pada bagaimana menciptakan komunikasi yang baik dengan pelanggan untuk tetap setia pada produk yang ditawarkan dalam jangka panjang. Dalam upaya mengetahui minat pelanggan, maka penting bagi perusahaan mengetahui pelanggannya agar dapat menjadi lebih dekat dengan mereka. Hal tersebut dapat dilakukan dengan cara mengumpulkan informasi dan mengumpulkannya dalam customer database [2].

Perkembangan TI menghasilkan peluang dan tantangan untuk organisasi pariwisata sehingga perlu menggunakan TI untuk mengembangkan strategi yang fokus pada pelanggan, mendorong profitabilitas, dan memampukan kemitraan yang terlibat. Penerapan TI yang sukses membutuhkan manajemen yang inovatif dalam meninjau perkembangan dan mengadopsi solusi teknologi yang cocok untuk memaksimalkan daya saing organisasi [3].

Namun hingga saat ini, Perum Perhutani Unit III belum mempunyai perancangan enteprise architecture untuk menunjang pemasaran destinasi wisata dan pengelolaan hubungan pelanggan. Salah satu Wana Wisata Perum Perhutani Unit III yaitu: Pantai Karangniri, menghadapi permasalahan dalam promosi. Menurut Koordinator Pengelola Wana Wisata Pantai Karangnini kegiatan promosi yang dilakukan masih kurang, dikarenakan media promosi yang saat ini digunakan hanya melalui website internet Wana Wisata Perum Perhutani [4]. Perum Perhutani Unit III juga kurang concern terhadap penanganan keluhan yang hanya melalui hotline dan penyebaran kuesioner secara manual serta implementasi management hubungan pelanggan (CRM) yang dapat meningkatkan kepuasan dan loyalitas pelanggan.

Berdasarkan pada permasalahan diatas, Perum Perhutani Unit III membutuhkan perancangan enteprise architecture melalui pemanfaatan dan penyelasarasan teknologi informasi. Perancangan enterprise architecture dilakukan dengan menggunakan framework TOGAF sebagai panduan dalam melakukan perancangan. TOGAF merupakan sebuah metode yang digunakan dalam memodelkan pengembangan sebuah enterprise architecture. Pemilihan TOGAF ADM sebagai framework dalam merancang enterprise architecture karena TOGAF ADM memiliki sifat iteratif dan terbuka pada perubahan dan hal itu sesuai dengan kondisi pada industri pariwisata Perum Perhutani Unit III yang terus berkembang dalam bidang bisnis maupun teknologi [5]. 


\section{STUDI LITERATUR}

\section{A. Enterprise architecture}

Enterprise architecture merupakan praktek manajemen yang mengintegrasikan perencanaan strategi, bisnis, dan teknologi sehingga perusahaan mempunyai pandangan yang membantu perusahaan dalam membuat rencana dan keputusan yang lebih baik. Enterprise architecture menggambarkan perencanaan teknologi, dengan menambahkan perencanaan strategis sebagai pendorong utama dari perusahaan, dan perencanaan bisnis sebagai kebutuhan dari sumber daya $[6]$.

\section{B. Framework}

Framework merupakan struktur untuk memodelkan bisnis dan IT suatu perusahaan dengan mengidentifikasi ruang lingkup dan hubungan dari area arsitektur. Framework dapat memudakan untuk merancang serta mengembangkan sistem, dikarenakan tahapantahapan, metode dan struktur logis yang telah disediakan oleh framework. Terdapat beberapa framework sebagai metodologi dalam memodelkan enterprise architecture yaitu: EAP, TOGAF, DODAF, Gartner dan FEA. Perbandingan antar framework sebagai metodologi dalam memodelkan enterprise architecture dipetakan ke dalam tiga kategori yaitu: konsep, model, dan proses [7]. Berdasarkan perbandingan dengan framework lain, TOGAF memiliki nilai tertinggi dalam semua aspek yang disebutkan. Pada kategori konsep, TOGAF memberikan tata kelola dan repositori yang paling tepat dengan memanfaatkan spesifik model. Pada kategori model, TOGAF memberikan dokumen yang luas tentang metode dan proses. Sedangkan pada kategori proses TOGAF memandang pelaksanaan enterprise architecture sebagai proses yang terus-menerus, sehingga lebih fokus pada kontinum dan repositori.

Pemilihan framework TOGAF disertai pertimbangan bahwa TOGAF merupakan metode yang fleksibel dan dapat mengantifikasi berbagai macam teknik pemodelan yang digunakan dalam perancangan, dapat disesuaikan dengan perubahan dan kebutuhan selama perancangan dilakukan, menyatakan visi dan prinsip yang jelas terhadap bagaimana melakukan pengembangan enterprise architecture, dapat dikolaborasikan dengan framework lain, dan mampu mengakomodasi proses bisnis yang transaksional [8].

\section{TOGAF ADM}

TOGAF Architecture Development Method (ADM) merupakan sebuah metode untuk mengembangkan dan mengelola siklus hidup suatu enterprise architecture dan mengintegrasikan elemen TOGAF serta aset arsitektur untuk memenuhi kebutuhan bisnis dan TI dari suatu organisasi. TOGAF ADM juga menyediakan proses proses iterarif yang memungkinkan perusahaan mendefinisikan kebutuhan bisnis dan membangun arsitektur secara spesifik.

Gambar 1 menjelaskan mengenai tahapan-tahapan TOGAF ADM dalam membangun enterprise architecture, yang terdiri dari: preliminary phase, architecture vision, architecture business, information system architecture, technology architecture, opportunities and solution, migration planning, implementation governance, architecture change management, dan requirement management [9].

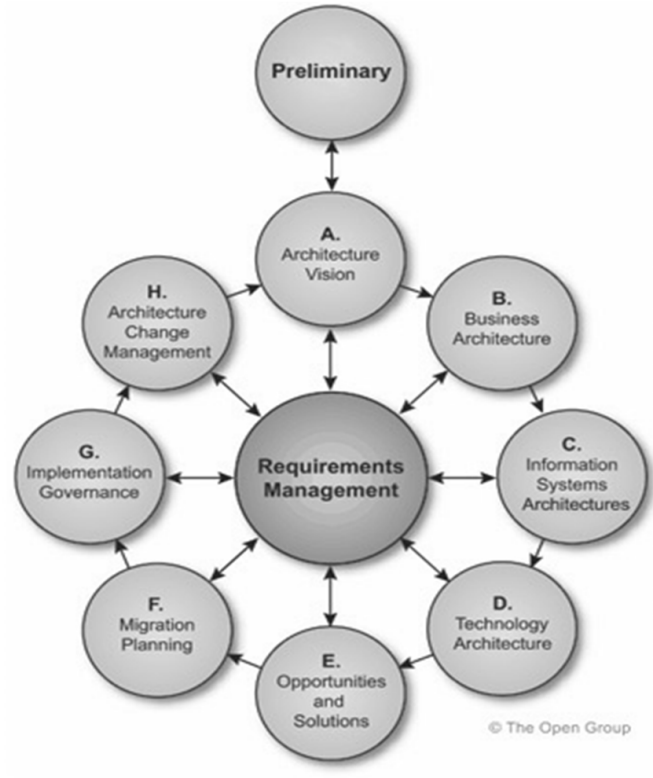

Gambar 1 Architecture Development Cycle

\section{METODOLOGI PENELITIAN}

Metodologi yang digunakan menggunakan model konseptual yang merupakan gambaran terstruktur berdasarkan teori dan hipotesis yang berkaitan dengan penelitian yang sedang di lakukan. Model ini menjelaskan serangkaian kerangka berpikir yang terstruktur secara ringkat untuk menghasilkan output yang sesuai dengan tujuan penelitian [10].

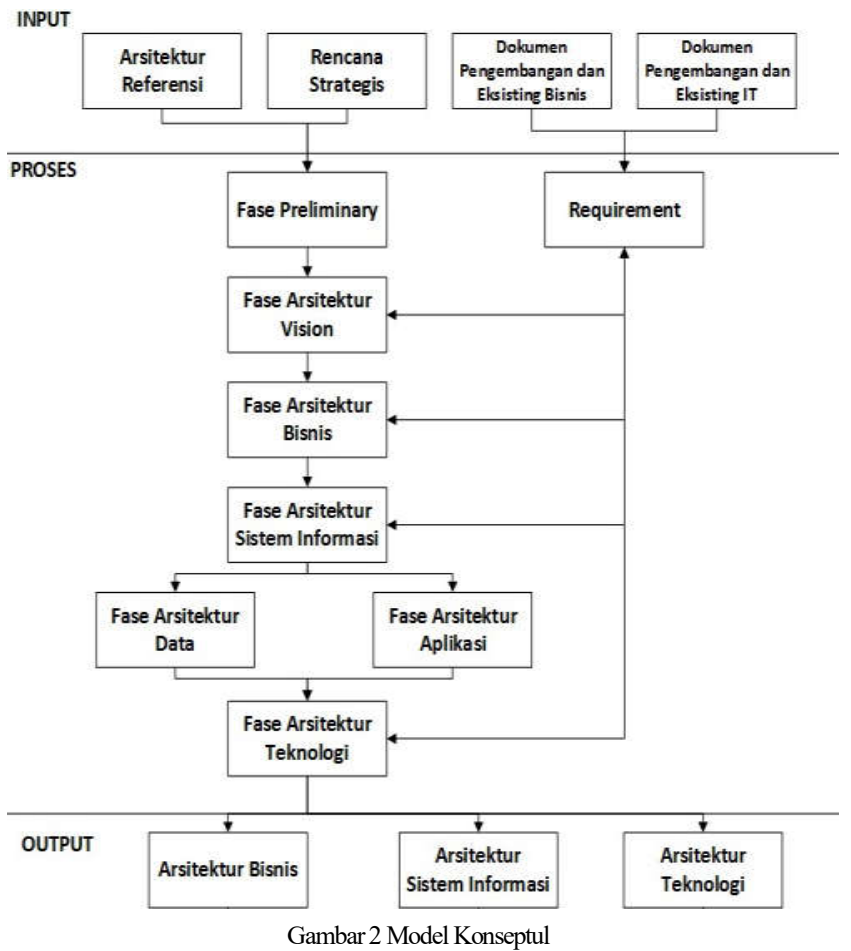


Gambar 2 merupakan model konseptual yang memiliki tiga elemen utama yaitu input, proses, dan output. Dalam merancang setiap arsitektur dibutuhkan input berupa arsitektur referensi, rencana strategis perusahaan, dokumen pengembangan bisnis dan IT eksisting pada Perum Perhutani Unit III. Input tersebut akan digunakan dalam proses perancangan arsitektur berdasarkan tahapan dari TOGAF ADM. Proses tersebut akan menghasilkan arsitektur bisnis, arsitektur sistem informasi, dan arsitektur teknologi yang menjadi usulan pengembangan bagi perusahaan.

\section{HASIL DAN ANALISIS}

\section{A. Fase Preliminary}

Fase preliminary merupakan tahap persiapan dalam melakukan inisiasi aktivitas aktivitas yang diperlukan untuk memenuhi tujuan bisnis. Fase ini akan menghasilkan principles catalog yang berisi prinsip-prinsip arsitektur yang digunakan sebagai dasar dan panduan dalam membuat rancangan enterprise architecture. Tabel I merupakan principle catalog dari Perum Perhutani Unit III.

TABEL I

PRINCIPLECATALOG

\begin{tabular}{|c|c|}
\hline Principles & Business Principles \\
\hline \multirow{3}{*}{$\begin{array}{l}\text { Pemanfaatan } \\
\text { teknologi } \\
\text { informasi }\end{array}$} & $\begin{array}{l}\text { Menerapkan proses TI dan infrastruktur untuk } \\
\text { memenuhi solusi kebutuhan yang ditetapkan serta } \\
\text { tingkat layanan seperti adanya sentralisasi reservasi. }\end{array}$ \\
\hline & $\begin{array}{l}\text { Mempromosikan destinasi wisata melalui pemanfaatan } \\
\text { media sosial. }\end{array}$ \\
\hline & $\begin{array}{l}\text { Menyediakan kemudahan bagi pelayanan untuk } \\
\text { membeli penawaran jasa pariwisata melalui pembelian } \\
\text { multichannel mengunakan website, mobile apps, dan } \\
\text { partner penjualan online. }\end{array}$ \\
\hline & $\begin{array}{l}\text { Memberikan pelayanan terabaik kepada pelanggan } \\
\text { dengan pembentukan bagian layanan pelanggan } \\
\text { sehingga dapat menangani keluhan secara transparan. }\end{array}$ \\
\hline & $\begin{array}{l}\text { Meningkatkan kepuasan pelanggan dengan melakukan } \\
\text { perbaikan kinerja melalui feedback pelanggan. }\end{array}$ \\
\hline $\begin{array}{l}\text { Pemeliharaan } \\
\text { fasilitas }\end{array}$ & $\begin{array}{l}\text { Menyediakan fasilitas yang memberikan kenyamanan bagi } \\
\text { pelanggan. }\end{array}$ \\
\hline \multirow{2}{*}{$\begin{array}{l}\text { Pengembangan } \\
\text { bisnis dan } \\
\text { penentuan target }\end{array}$} & \begin{tabular}{|lll}
$\begin{array}{l}\text { Memastikan keselarasan } \\
\text { dengan tujuan perusahaan }\end{array}$ & pencapaian target \\
\end{tabular} \\
\hline & $\begin{array}{l}\text { Melakukan perencanaan dan pengembangan bisnis } \\
\text { guna meningkatkan ekspansi pasar. }\end{array}$ \\
\hline Principles & Data Principles \\
\hline Data aset & $\begin{array}{l}\text { Data merupakan sumber daya Perum Perhutani sebagai } \\
\text { data pengelolaan data maupun informasi. }\end{array}$ \\
\hline Sharing data & \begin{tabular}{|llll}
$\begin{array}{l}\text { Data dibagi ke seluruh fungsi perusahaan dan } \\
\text { organisasi terkait. }\end{array}$ & & \\
\end{tabular} \\
\hline \begin{tabular}{|l|} 
Data dapat \\
diakses
\end{tabular} & $\begin{array}{l}\text { Data dapat diakses bagi pengguna untuk melakukan } \\
\text { fungsi. }\end{array}$ \\
\hline Data terpercaya & Data sesui dengan informasi yang sebenarnya. \\
\hline Principles & Application Principles \\
\hline Easy-of-Use & $\begin{array}{l}\text { Aplikasi dan web yang digunakan Perum Perhutani } \\
\text { mudah digunakan baik bagi customer maupun pegawai } \\
\text { berbasis user friendly. }\end{array}$ \\
\hline Integrasi & $\begin{array}{l}\text { Aplikasi dapat mengintegrasikan antar proses bisnis } \\
\text { dan antar data. }\end{array}$ \\
\hline $\begin{array}{l}\text { Technology } \\
\text { independence }\end{array}$ & $\begin{array}{l}\text { Teknologi aplikasi yang dapat beroperasi digunakan } \\
\text { pada berbagai platform. }\end{array}$ \\
\hline Principles & Technology Principles \\
\hline Payment & $\begin{array}{l}\text { Pembayaran dapat dilakukan menggunakan sistem } \\
\text { pembayaran elektronik }(e \neg \text {-payment })\end{array}$ \\
\hline
\end{tabular}

\begin{tabular}{|l|l|}
\hline Interoperability & $\begin{array}{l}\text { Software dan hardware yang digunakan sesuia dengan } \\
\text { standar yang dibutuhkan pada interoperabilitas untuk } \\
\text { data, aplikasi dan teknologi. }\end{array}$ \\
\hline $\begin{array}{l}\text { Responsive } \\
\text { Change } \\
\text { Management }\end{array}$ & $\begin{array}{l}\text { Perubahan Informasi Perum Perhutani dapat update } \\
\text { secara tepat waktu guna untuk memberi informasi yang } \\
\text { akurat. }\end{array}$ \\
\hline
\end{tabular}

\section{B. Fase Architecture Vision}

Fase architecture vision merupakan fase pertama dalam pengembangan enterprise architecture pada TOGAF ADM. Fase architecture vision menggambarkan bagaimana enterprise architecture yang akan dibuat dapat memenuhi tujuan bisnis dan sasaran strategis perusahaan. Fase ini akan menghasilkan artifak berupa business model canvas dan solution concept diagram.

\section{Business Model Canvas}

Business model canvas menggambarkan pemodelan bisnis yang akan dicapai dengan merepresentasikan elemen-elemen kunci, yaitu: key partners, key activities value proposition, customer relationships, customer segments, key resource, channels, revenue stream, dan cost structure. Tabel II merupakan business model canvas dari Perum Perhutani Unit III, dimana bagian yang berwarna lebih gelap merupakan elemen baru yang akan diimplementasikan pada bisnis.

TABEL II

BUSINESS MODEL CANVAS

\begin{tabular}{|c|c|c|c|c|c|}
\hline $\begin{array}{l}\text { Key Partners } \\
\text { - Sekolah } \\
\text { - Perusahaan } \\
\text { - Shuttle } \\
\text { - Travel Agent } \\
\text { - Online Travel } \\
\text { Agent \& Hotel } \\
\text { - Airline } \\
\text { - Hotel } \\
\text { - Pusat Oleh- } \\
\text { oleh }\end{array}$ & $\begin{array}{l}\text { Key Activities } \\
\text { - Destinasi } \\
\text { Wisata } \\
\text { Alam } \\
\text { - Rekreasi \& } \\
\text { Hiburan } \\
\text { - Hotel \& } \\
\text { Resorts } \\
\text { - Tour Guide } \\
\text { - Customer } \\
\text { - Service } \\
\text { - Culture } \\
\text { Exhibition }\end{array}$ & \multicolumn{2}{|c|}{$\begin{array}{l}\text { Volue Proposition } \\
\text { - Pariwisata sumber } \\
\text { daya hutani } \\
\text { - Dikenal di } \\
\text { masyarakat luas } \\
\text { - Pilihan paket } \\
\text { bervariasi } \\
\text { - Pelayanan ramah } \\
\text { - Harga terjangkau } \\
\text { - Kemudahan akses } \\
\text { - Pelanggan dapat } \\
\text { membuat paket } \\
\text { destinasi wisata } \\
\text { sendiri }\end{array}$} & $\begin{array}{l}\text { Customer } \\
\text { Relationships } \\
\text { - Hotline } \\
\text { - Potongan harga } \\
\text { membership } \\
\text { - Penanganan } \\
\text { keluhan melalui } \\
\text { website } \\
\text { - Pemesanan layanan } \\
\text { jasa dari berbagai } \\
\text { Channet: Website. } \\
\text { Mobile App. dan } \\
\text { Partner } \\
\text { - Penginkatan } \\
\text { layanan melalui } \\
\text { informasi } \\
\text { Komunitas Online } \\
\text { Chonnels } \\
\text { - Hotline } \\
\text { - Website } \\
\text { - Partner } \\
\text { - Social Media } \\
\text { - Mobile Apps }\end{array}$ & $\begin{array}{l}\text { Customer } \\
\text { Segments } \\
\text { - Keluarga } \\
\text { - PelajarI } \\
\text { Mahasiswa } \\
\text { - Anak-anak } \\
\text { - Pasangan } \\
\text { muda } \\
\text { - Traveler } \\
\text { - Perusahaan }\end{array}$ \\
\hline \multicolumn{3}{|c|}{$\begin{array}{l}\text { Cost Structure } \\
\text { - Upah tenaga kerja } \\
\text { - Pemeliharaan penunjang operasional } \\
\text { - Biaaya Promosi : Baliho, Spanduk Poster } \\
\text { - Social Media Advertising } \\
\text { - Website maintenance }\end{array}$} & \multicolumn{3}{|c|}{$\begin{array}{l}\text { Revenue Streams } \\
\text { - Penjualan Tiket } \\
\text { - Penjualan Souvenir } \\
\text { - Pendapatan Hotel \& Resorts } \\
\text { - Penyewaan Akomodasi } \\
\text { - Pemesanan Online }\end{array}$} \\
\hline
\end{tabular}

2. Solution Concept Diagram

Solution concept diagram menggambarkan konsep usulan yang akan diterapkan, usulan tersebut akan digambarkan secara garis besar untuk menampilkan solusi yang diharapkan perusahaan. Gambar 3 merupakan solution concept diagram yang di rancang untuk Perum Perhutani Unit III sehingga perusahaan dapat mencapai tujuannya. Solution concept diagram terdiri dari empat layer, yaitu channel, front office, mid office, dan back office.

Channel menununjukkan cara user untuk mengakses front office berupa westjavatourism mobile, westjavatourism.co.id, dan third-party interface partner melalui internet, intranet, mobile, dan social media. Middle office merupakan bagian yang menunjang jalannya kegiatan bisnis perusahaan seperti bagian operasional, 
pemasaran \& CRM, dan perencanaan bisnis yang dibutuhkan untuk mengimplementasi website, mobile apps, dan aplikasi internal.

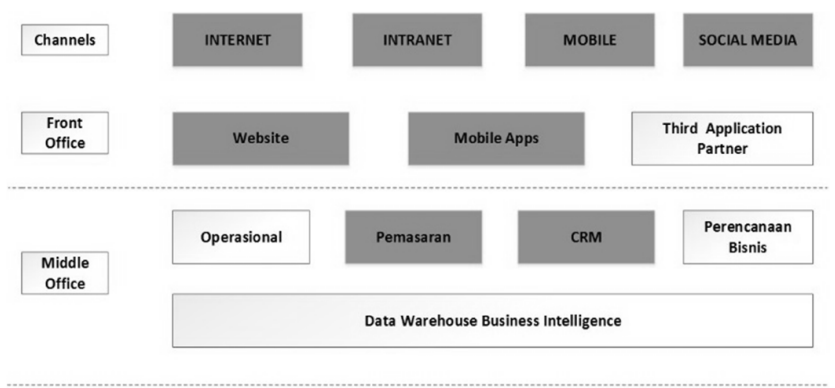

Back Office

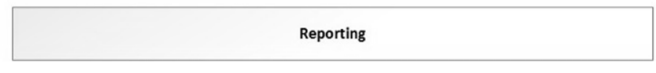

Gambar 3 Solution Concept Diagram

Aplikasi internal ini dirancang untuk melakukan koordinasi dengan seluruh divisi, fungsi, serta kantor yang terdapat dalam perusahaan, serta menunjang untuk melakukan pertukaran data, informasi, dan pelaporan yang diperlukan. Back office berupa administrasi \& keuangan, dan reporting merupakan bagian yang menerima pelaporan dari hasil kegiatan bisnis yang dilakukan oleh front office dan middle office. Back office memiliki fungsi monitoring serta mengolah data menjadi pelaporan.

\section{Fase Business Architecture}

Fase business architecture merupakan fase kedua dalam pengembangan enterprise architecture pada TOGAF ADM. Business architecture menjelaskan tentang strategi bisnis, pengelolaan, organisasi, dan menggambarkan proses bisnis utama yang terjadi pada perusahaan. Tabel III merupakan process business catalog pada fungsi pemasaran dan CRM di Perum Perhutani Unit III. Proses bisnis utama dari fungsi pemasaran adalah perencanaan strategi pemasaran dan penyusunan marketing plan. Proses bisnis penyusunan marketing plan dilakukan bersama dengan fungsi perencanan bisnis, dimana pengolahan data survei pasar, pelanggan, dan pesaing dilakukan oleh fungsi pemasaran. Proses bisnis perencanaan strategi pemasaran memiliki sub proses bisnis, yaitu: pengembangan layanan jasa baru, penentuan harga layanan jasa, dan perencanaan kegiatan promosi.

Fungsi pemasaran membutuhkan aplikasi pemasaran yang dapat mendukung kegiatan bisnis dalam menampung data survei sehingga lebih mudah untuk diolah dan dapat digunakan untuk kepentingan lain. Aplikasi pemasaran juga dapat digunakan untuk menyimpan dan memverifikasi laporan survei, partner layanan jasa, usulan kegiatan strategi pemasaran dan laporan hasil usulan tersebut. Dalam mendukung aplikasi tersebut, pemasaran membutuhkan website dan mobile apps yang dapat membantu memberikan informasi mengenai layanan jasa dan harga layanan jasa serta melakukan kegiatan promosi sehingga dapat dengan mudah diketahui oleh pelanggan.

Proses bisnis fungsi CRM terkait dengan penanganan keluhan dan pengelolaan feedback, kemudian terdapat penambahan proses bisnis pendaftaran membership dan pemberian reward pelanggan. Adanya penambahan proses bisnis baru yaitu: pendaftaran membership dan pemberian reward pelanggan, bertujuan untuk menjaga hubungan dengan pelanggan dan memberikan reward terhadap loyalitas pelanggan selama ini.

Fungsi CRM membutuhkan aplikasi CRM dalam menangani data keluhan, mengelola data membership dan data reward pelanggan serta pengolahan data kuesioner. Dalam mendukung aplikasi tersebut, CRM membutuhkan website dan mobile apps yang dapat diakses pelanggan dalam menyampaikan keluhan, mengisi kueisoner, mendaftar sebagai member, serta mengetahui status keluhan dan jumlah point reward yang dimiliki pelanggan.

TABEL III

PROCESS BUSINESS CATALOG

\begin{tabular}{|c|c|c|}
\hline No & Proses Bisnis & Deskripsi \\
\hline \multicolumn{3}{|r|}{ Pemasaran } \\
\hline 1 & $\begin{array}{l}\text { Proses bisnis } \\
\text { penyusunan } \\
\text { marketing plan }\end{array}$ & $\begin{array}{l}\text { Proses bisnis penyusunan marketing plan dilakukan } \\
\text { untuk mengolah data survei kondisi, pasar, } \\
\text { pelanggan, dan pesaing yang digunakan untuk } \\
\text { menghaislkan rekomendasi perbaikan dan target } \\
\text { pemasaran. }\end{array}$ \\
\hline 2 & $\begin{array}{l}\text { Proses bisnis } \\
\text { perekrutan } \\
\text { partner } \\
\text { layanan jasa } \\
\end{array}$ & $\begin{array}{l}\text { Proses bisnis perekrutan partner layanan jasa } \\
\text { dilakukan untuk mengolah data partner layanan } \\
\text { dalam melakukan diversifikasi layanan jasa melalui } \\
\text { layanan jasa yang dimiliki oleh partner. }\end{array}$ \\
\hline 3 & $\begin{array}{l}\text { Proses bisnis } \\
\text { pengembangan } \\
\text { layanan jasa } \\
\text { baru }\end{array}$ & $\begin{array}{l}\text { Salah satu sub proses dalam menentukan strategi } \\
\text { pemasaran adalah pengembangan layanan jasa baru. } \\
\text { Layanan jasa baru dibuat sesuai dengan kondisi } \\
\text { pasar dan keinginan pelanggan sehingga dapat } \\
\text { memuaskan kebutuhan pelanggan. }\end{array}$ \\
\hline 4 & $\begin{array}{l}\text { Proses bisnis } \\
\text { penentuan } \\
\text { harga layanan } \\
\text { jasa }\end{array}$ & $\begin{array}{l}\text { Salah satu sub proses dalam menentukan strategi } \\
\text { pemasaran adalah penentuan harga layanan jasa. } \\
\text { Harga layanan jasa baru dibuat sesuai dengan } \\
\text { kondisi pasar, pesaing dan keinginan pelanggan } \\
\text { sehingga dapat menarik pelanggan untuk membeli } \\
\text { layanan jasa tersebut. }\end{array}$ \\
\hline 5 & $\begin{array}{l}\text { Proses bisnis } \\
\text { promosi }\end{array}$ & $\begin{array}{l}\text { Salah satu sub proses dalam menentukan strategi } \\
\text { pemasaran adalah menentukan promosi. Promosi } \\
\text { merupakan hal yang penting karena dapat } \\
\text { membantu dalam memberikan informasi tentang } \\
\text { jasa layanan dan menarik pelanggan untuk membeli } \\
\text { layanan jasa tersebut. }\end{array}$ \\
\hline \multicolumn{3}{|r|}{ CRM } \\
\hline 6 & $\begin{array}{l}\text { Proses bisnis } \\
\text { penanganan } \\
\text { keluhan }\end{array}$ & $\begin{array}{l}\text { Proses penanganan keluhan dilakukan untuk } \\
\text { menampung dan menangani setiap masalah yang } \\
\text { dihadapi oleh pelanggan sehingga dapat } \\
\text { meningkatkan kepuasan dan kesetian pelangan } \\
\text { terhadap perusahaan }\end{array}$ \\
\hline 7 & $\begin{array}{l}\text { Proses bisnis } \\
\text { pengelolaan } \\
\text { feedback }\end{array}$ & $\begin{array}{l}\text { Proses pengelolaan feedback dilakukan untuk } \\
\text { melihat bagaimana kepuasan pelanggan terhadap } \\
\text { layanan jasa yang diberikan. }\end{array}$ \\
\hline 8 & $\begin{array}{l}\text { Proses bisnis } \\
\text { pendaftaran } \\
\text { membership }\end{array}$ & $\begin{array}{l}\text { Proses bisnis pendaftaran membership merupakan } \\
\text { proses bisnis usulan yang dilakukan untuk menjaga } \\
\text { hubungan baik dan meningkatkan loyalitas } \\
\text { pelanggan. }\end{array}$ \\
\hline 9 & $\begin{array}{l}\text { Proses bisnis } \\
\text { pemberian } \\
\text { reward } \\
\text { pelanggan }\end{array}$ & $\begin{array}{l}\text { Pelanggan yang mendaftar menjadi member akan } \\
\text { mendapatkan reward berupa point penawaran untuk } \\
\text { diskon pembelian layanan jasa. }\end{array}$ \\
\hline
\end{tabular}

D. Fase Information System Architecture

Fase information system merupakan tahapan ketiga dalam fase TOGAF ADM. Fase ini menjelaskan alur distribusi data dan aplikasi yang dibutuhkan untuk mendukung proses bisnis perusahaan.

1. Fase Data Architecture

Fase data architecture merupakan bagian dari fase information system architecture. Fase ini bertujuan untuk mengidentifikasi kandidat entitas data di perusahaan serta memetakan entitas tersebut 
ke dalam logical application component. Dalam mengidentifikasi entitas data dapat dilakukan dengan memetakan proses bisnis dengan data input yang dibutuhkan saat melakukan proses bisnis dan data ouput yang menjadi hasil dari proses bisnis tersebut. Tabel IV menjelaskan hasil pemetaan antara proses bisnis dengan data input dan data output.

TABEL IV

IDENTIFIKASI DATA ENTITY

\begin{tabular}{|c|c|c|}
\hline Proses Bisnis & Data Input & Data Output \\
\hline \multicolumn{3}{|c|}{ Pemasaran } \\
\hline $\begin{array}{l}\text { Penyusunan } \\
\text { marketing plan }\end{array}$ & $\begin{array}{l}\text { - Pesaing } \\
\text { - Pelanggan } \\
\text { - Potensial pelanggan } \\
\text { - Kondisi pasar }\end{array}$ & $\begin{array}{l}\text { - Target pemasaran } \\
\text { - Rekomendasi perbaikan }\end{array}$ \\
\hline $\begin{array}{l}\text { Perekrutan } \\
\text { partner } \\
\text { layanan jasa }\end{array}$ & $\begin{array}{l}\text { - Potensial partner } \\
\text { layanan jasa }\end{array}$ & $\begin{array}{l}\text { - Partner layanan jasa } \\
\text { - Perjanjian kerja sama }\end{array}$ \\
\hline $\begin{array}{l}\text { Pengembangan } \\
\text { layanan jasa } \\
\text { baru }\end{array}$ & $\begin{array}{l}\text { - Pesaing } \\
\text { - Pelanggan } \\
\text { - Potensial pelanggan } \\
\text { - Kondisi pasar } \\
\text { - Layanan jasa } \\
\text { - Produk Perhutani } \\
\text { - Layanan jasa partner }\end{array}$ & - Usulan layanan jasa \\
\hline $\begin{array}{l}\text { Penentuan } \\
\text { harga layanan } \\
\text { jasa }\end{array}$ & $\begin{array}{l}\text { - Pesaing } \\
\text { - Pelanggan } \\
\text { - Potensial pelanggan } \\
\text { - Kondisi pasar } \\
\text { - Layanan jasa } \\
\text { - Produk Perhutani } \\
\text { - Layanan jasa partner }\end{array}$ & - Usulan harga layanan jasa \\
\hline $\begin{array}{l}\text { Perencanaan } \\
\text { kegiatan } \\
\text { promosi }\end{array}$ & $\begin{array}{l}\text { - Target pemasaran } \\
\text { - Pesaing } \\
\text { - Pelanggan } \\
\text { - Potensial pelanggan } \\
\text { - Kondisi pasar } \\
\text { - Produk Perhutani } \\
\text { - Layanan jasa } \\
\text { - Partner penjualan } \\
\text { - History order }\end{array}$ & $\begin{array}{l}\text { - Usulan kegiatan promosi } \\
\text { personal } \\
\text { - Usulan kegiatan promosi } \\
\text { produk Perhutani } \\
\text { - Usulan kegiatan promosi } \\
\text { layanan jasa } \\
\text { - Usulan kegiatan promosi } \\
\text { partner penjualan }\end{array}$ \\
\hline \multicolumn{3}{|c|}{ CRM } \\
\hline $\begin{array}{l}\text { Penangan } \\
\text { Keluhan }\end{array}$ & $\begin{array}{l}\text { - Pelanggan } \\
\text { - Transaksi order } \\
\text { - Keluhan } \\
\text { - Tindak lanjut keluhan } \\
\text { - History keluhan } \\
\end{array}$ & $\begin{array}{l}\text { - Tindak lanjut keluhan } \\
\text { - History keluhan }\end{array}$ \\
\hline $\begin{array}{l}\text { Pengelolaan } \\
\text { feedback }\end{array}$ & - Transaksi order & - Feedback \\
\hline $\begin{array}{l}\text { Pendaftaran } \\
\text { membership }\end{array}$ & - Pelanggan & - Membership \\
\hline $\begin{array}{l}\text { Pemberian } \\
\text { point reward }\end{array}$ & $\begin{array}{l}\text { - Pelanggan } \\
\text { - Transaksi order } \\
\text { - Point layanan jasa } \\
\text { - Point produk } \\
\text { Perhutani }\end{array}$ & - Penerimaan point reward \\
\hline
\end{tabular}

Berdasaran identifikasi di atas, maka entitas data pada fungsi pemasaran dan CRM Perum Perhutani Unit III telah diketahui dan dapat digunakan untuk menghasilkan artifak berupa data dissemination diagram. Data dissemination diagram merupakan diagram yang menggambarkan hubungan antara business service, entitas data, dan komponen aplikasi. Diagram ini menunjukkan bagaimana business service yang dimiliki perusahaan terhubung dengan logical application yang di dalamnya terdapat entitas data. Gambar 4 merupakan data dissemination diagram pada fungsi pemasaran di Perum Perhutani Unit III. Fungsi pemasaran memiliki empat business service, yaitu: penyusunan marketing plan, pengembangan layanan jasa baru, penentuan harga layanan jasa, dan perencanaan kegiatan promosi. Setiap business service dipetakan ke dalam logical component application, yaitu: pengelolaan survei, pengelolaan layanan jasa, pengelolaan harga layanan jasa, dan pengelolaan promosi.

Gambar 5 merupakan data dissemination diagram pada fungsi CRM di Perum Perhutani Unit III. Fungsi CRM memiliki empat business service, yaitu: penanganan keluhan, pengelolaan feedback, pendaftaran membership, dan pemberian reward pelanggan. Setiap business service dipetakan ke dalam logical component application, yaitu: pengelolaan keluhan, pengelolaan feedback, pengelolaan membership, dan pengelolaan reward pelanggan.

\section{Fase Application Architecture}

Fase application architecture merupakan bagian dari fase information system architecture. Fase ini bertujuan untuk menentukan jenis dari aplikasi yang diperlukan untuk memproses data dan mendukung jalannya aktivitas bisnis. Fase ini akan menghasilkan artifak berupa application communication diagram. Application communication diagram merupakan diagram yang menggambarkan hubungan antara logical application component dengan physical application component. Gambar 6 merupakan application communication diagram pada fungsi pemasaran dan CRM Perum Perhutani Unit III. Physical application component yang akan digunakan yaitu: website, mobile apps, aplikasi pemasaran, dan aplikasi CRM. Website dan mobile apps menangani pengelolaan layanan jasa, pengelolaan harga layanan jasa, pengelolaan promosi, pengelolaan keluhan, pengelolaan feedback, pengelolaan membership, dan pengelolaan reward pelanggan yang ditujukan untuk kemudahan pemberian informasi dari perusahaan dan kemudahan akses bagi pelanggan. Aplikasi pemasaran menangani pengelolaan survei, pengelolaan layanan jasa, pengelolaan harga layanan jasa, dan pengelolaan promosi yang digunakan untuk menampung dan mengolah data pemasaran dalam melakukan perencanaan strategi pemasaran. Sedangkan aplikasi CRM menangani pengelolaan keluhan, pengelolaan feedback, pengelolaan membership, dan pengelolan reward pelanggan yang digunakan untuk menampung dan mengolah data CRM pemasaran dalam menjaga hubungan baik dengan pelanggan. 


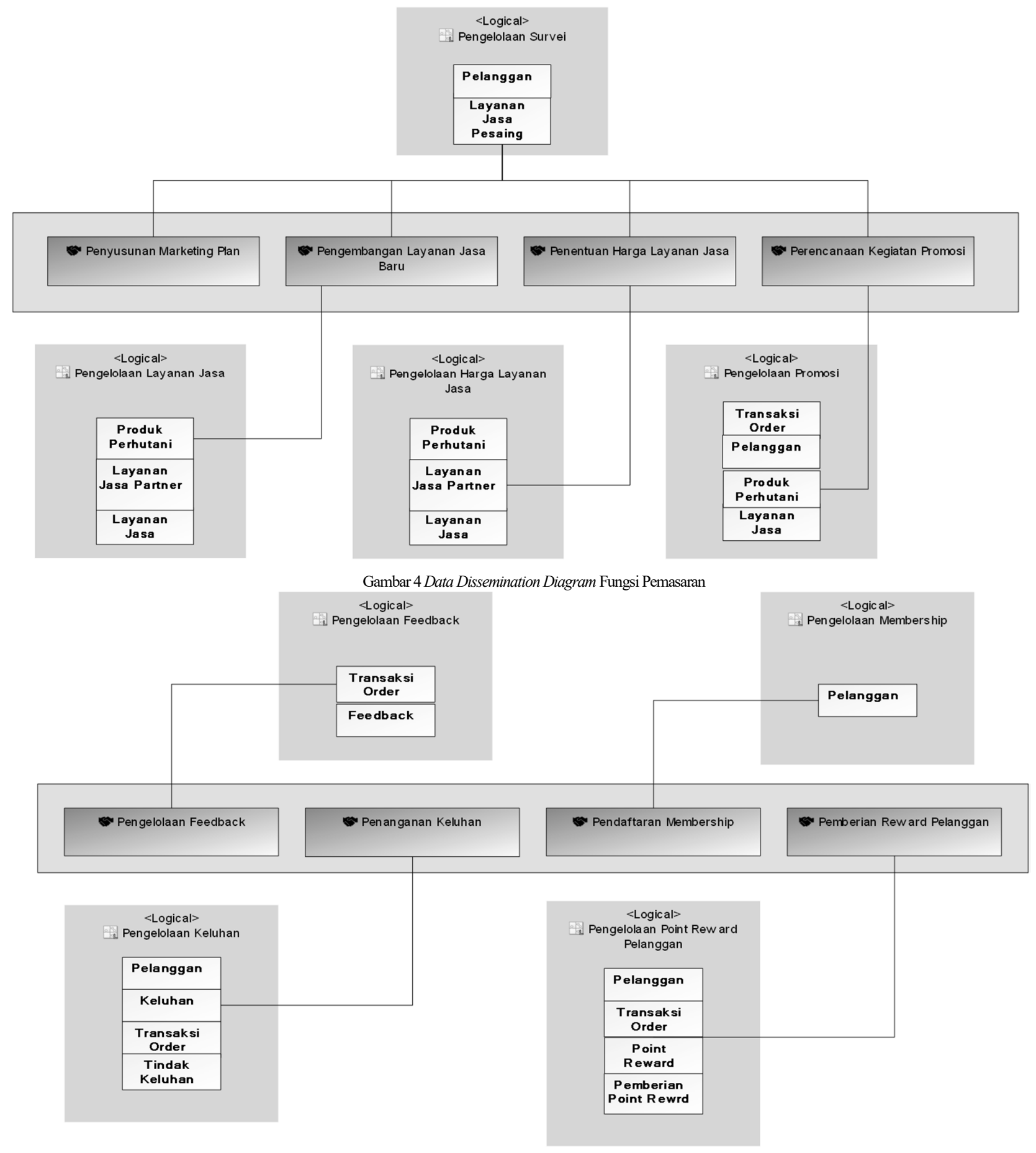

Gambar 5 Data Dissemination Diagram Fungsi CRM 


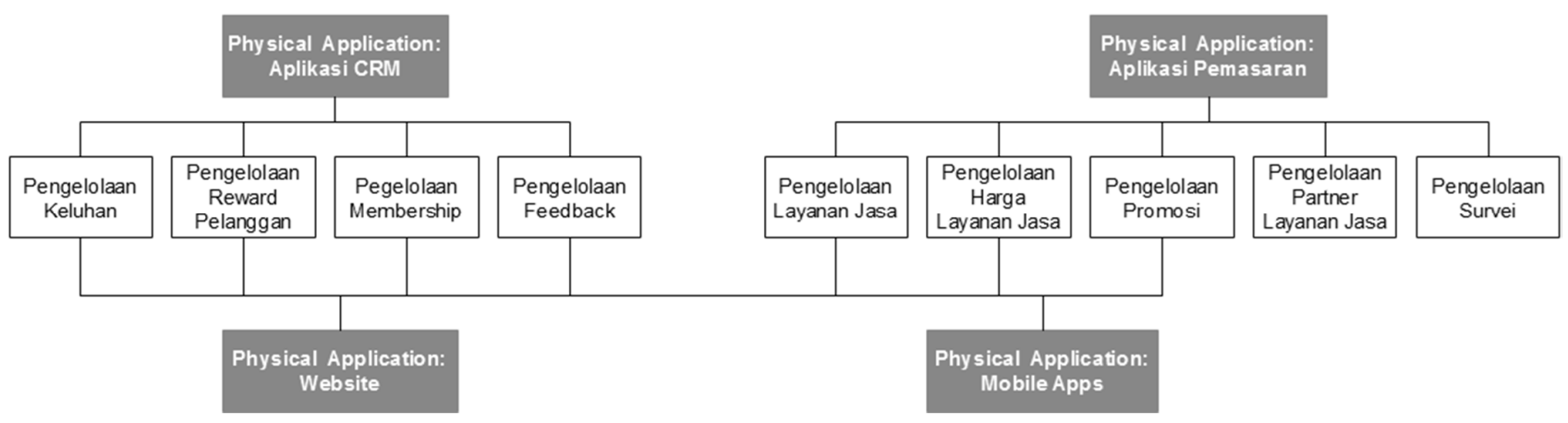

Gambar 6 Application Communication Diagram

\section{E. Fase Technology Architecture}

Fase technology architecture merupakan fase keempat pada TOGAF ADM. Fase ini bertujuan untuk membangun arsitektur teknologi berupa software, hardware, dan jaringan infrastruktur yang dibutuhkan untuk mendukung sharing data/ informasi di lingkungan perusahaan. Fase ini menghasilkan artifak, yaitu system/technology matrix, dan environments and locations diagram.

1. System//Technology Matrix

System/Technology Matrix digunakan untuk mengambarkan hubungan antara physical application component dan technology component. Tabel V merupakan system/technology matrix pada Perum Perhutani Unit III.

TABEL V

SYSTEM/TECHNOLOGYMATRLX

\begin{tabular}{|c|c|c|}
\hline $\begin{array}{c}\text { Physical Application } \\
\text { Component }\end{array}$ & $\begin{array}{c}\text { Logical Technology } \\
\text { Component }\end{array}$ & $\begin{array}{c}\text { Physical Technology } \\
\text { Component }\end{array}$ \\
\hline Aplikasi Internal & $\begin{array}{ll} & \text { Java } \\
\text { - } & \text { MYSQL } \\
\text { - } & \text { Web Service } \\
\end{array}$ & \multirow{3}{*}{$\begin{array}{ll}\text { - } & \text { PC Client } \\
\text { - } & \text { Router } \\
\text { - } & \text { Switch } \\
\text { - } & \text { Database Server } \\
\text { - } & \text { Web \& } \\
& \text { Application } \\
& \text { Server } \\
\text { - } & \text { Firewall } \\
\text { - } & \text { Internet Service } \\
& \text { Provider }\end{array}$} \\
\hline Website & $\begin{array}{ll}\text { - } & \text { HTML } \\
\text { - } & \text { PHP } \\
\text { - } & \text { Apache } \\
\text { - } & \text { MYSQL } \\
\text { - } & \text { Web Service }\end{array}$ & \\
\hline Mobile Apps & $\begin{array}{ll}\text { - } & \text { Java } \\
\text { - } & \text { Android Studio } \\
\text { - } & \text { Swift } \\
\text { - } & \text { Apache } \\
\text { - } & \text { MYSQL }\end{array}$ & \\
\hline
\end{tabular}

2. Environments and Location Diagram

Environments and location diagram digunakan untuk menggambarkan pemetaan insfrastruktur technology yang akan diterapkan dalam mendukung aplikasi serta kebutuhan bisnis yang sesuai dengan gambaran lokasi perusahaan. Gambar 7 merupakan environments and location diagram pada Perum Perhutani Unit III. Diagram ini menggambarkan integrasi antar kantor pusat dan lokasi destinasi wisata yang berbeda kota dengan pusat data center dan disaster recovery center yang dikelola oleh pihak ketiga.

Pada kantor pusat terdapat bagian perencanaan bisnis, layanan pelanggan, operasional, CRM, keuangan, dan IT yang dihubungkan ke switch core dan router kantor pusat. Switch core dan router kantor pusat digunakan bagian IT sebagai monitoring dan control jaringan yang ada diperusahaan termasuk pada data center, disaster recovery center dan kantor lokasi destinasi wisata. Kantor lokasi destinasi wisata menggunakan aplikasi operasional sehingga harus terhubung dengan kantor pusat. Agar terhubung dengan kantor pusat, perusahaan menggunakan jaringan wide area network dengan menggunakan metode virtual private network. Kantor pusat dan kantor lokasi destinasi wisata harus dapat terhubung dengan data center dan disaster recovery center sehingga membutuhkan jaringan wide area network dengan menggunakan metode virtual private network. Seluruh pelanggan dapat melakukan akses website dan mobile apps perusahaan dengan terhubung ke jaringan internet

Perancangan arsitektur yang dilakukan pada setiap fase menghasilkan artifak-artifak yang memperjelas tujuan dari fungsi pemasaran dan CRM dari sisi bisnis, teknologi, dan layanan bisnis. Perancangan enterprise architecture pada bisnis melakukan pengembangan pada proses bisnis lama dengan menambahkan penggunaan aplikasi serta menambah prose bisnis dalam mendukung tujuan fungsi pemasaran dan CRM. Perancangan pada pemodelan data disesuaikan dengan proses bisnis dan komponen aplikasi yang akan dikembangkan. Aplikasi yang dikembangkan berupa website, mobile apps, aplikasi pemasaran dan aplikasi CRM yang digunakan untuk menunjang kegiatan perencanaan strategi pemasaran dan pengelolaan hubungan pelanggan. Sedangkan perancangan teknologi dilakukan dengan memodelkan infrastruktur jaringan sesuai dengan lokasi kantor pusat dan kantor lokasi destinasi sehingga diharapkan mampu mendukung berjalannya aplikasi.

\section{KESIMPULAN}

Dari hasil analisis perancangan model bisnis dan enterprise architecture pada fungsi pemasaran dan CRM di Perum Perhutani Unit III, maka dapat diambil kesimpulan bahwa rancangan enterprise architecture menghasilkan arsitekur bisnis, arsitektur sistem informasi dan arsitektur teknologi yang dapat dijadikan pedoman perusahaan untuk menjalankan aktivitas bisnis dan mendukung tercapainya tujuan perusahaan. Penelitian ini hanya terbatas pada fase preliminary sampai dengan fase technology sehingga diharapkan penelitian berikutnya dapat memenuhi semua fase TOGAF ADM. 


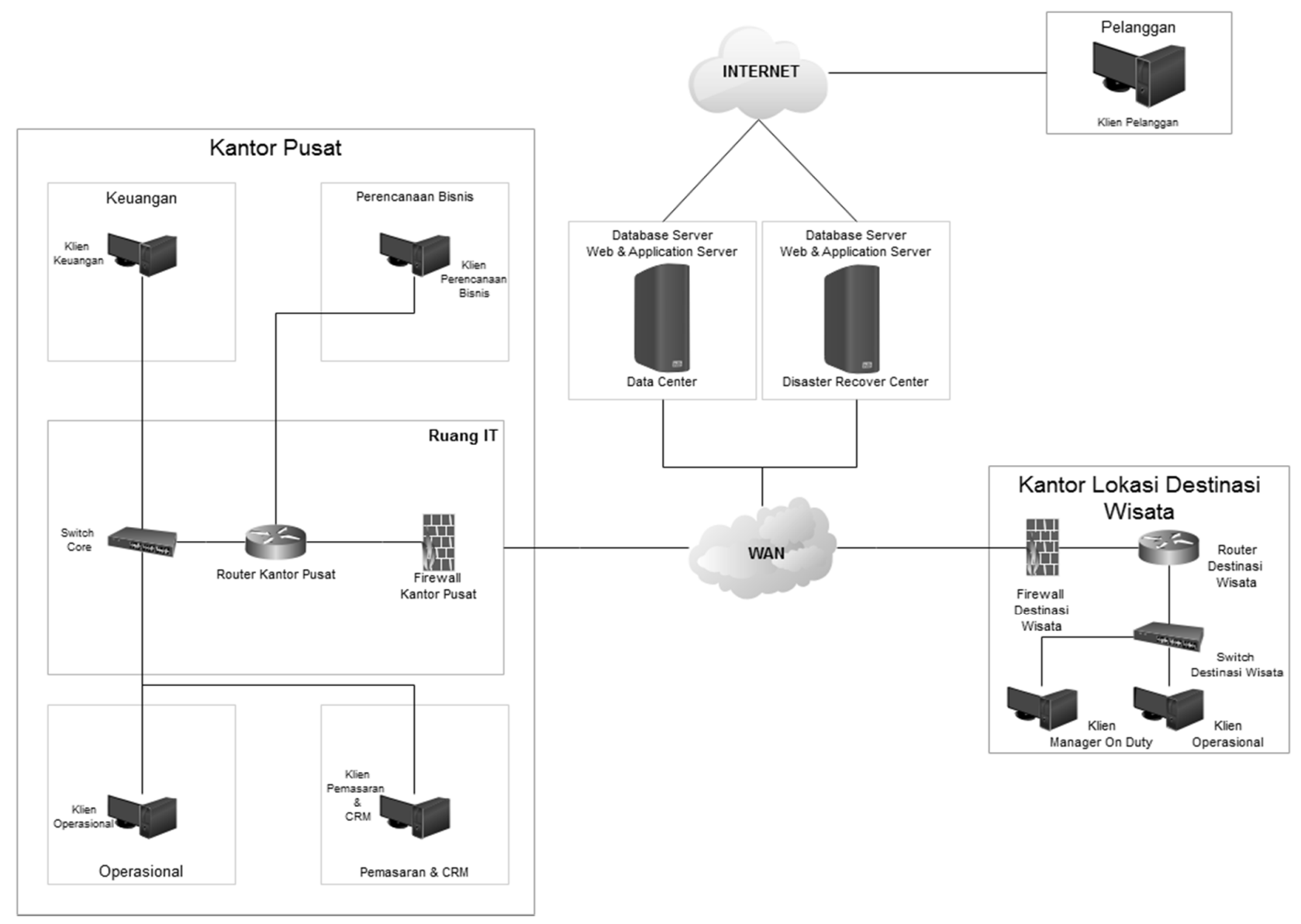

Gambar 7 Environments and Location Diagram

\section{DAFTAR PUSTAKA}

[1] Cox, C., \& Wray, M., Best Practice Marketing For Regional Tourism Destinations. Journal of Travel \& Tourism Marketing, Volume, 28, Number 5, 2011, pp. 524-540.

[2] Kotler, P., \& Keller, K. L., Marketing Management. London: Prentice Hall, 2009.

[3] Buhalis, D., \& O'Connor, P, Information Communication Technology Revolutionizing Tourism. Tourism Recreation Research, 30. pp. 7-16.

[4] Apriyanto, D., Studi Pengembangan Sistem Pemasaran Wana Wisata Karangniri KPH Ciamis Perum Perhutani III Jawa Barat dan Banten. Forest Management, pp 1-5.

[5] Indriani, R., Murahartawaty, M., \& Hanafi, R. (2016). Analisis dan Perancangan Technology Architecture Menggunakan The Open Group Architecture Framework Architecture Development Method (TOGAF ADM) pada PT Shafco Multi Trading. Jurnal Rekayasa Sistem \& Industri (JRSI), 3(01), 1-6

[6] Bernard, S, Using Enterprise Architecture to Integrate Strategic, Business, and Technology Planning. Journal of Enterprise Architecture, 2006, pp. 11.

[7] Rouhani, B., Mahrin, M., Nikpay, F., \& Nikfard, P, A Comparison Enterprise Architecture Implementation
Methodologies. International Conference on Informatics and Creative Multimedia, 2013, pp 1-5.

[8] Gandhil, Arfive., \& Kurniati, Angelina Prima., Perencanaan Strategis Sistem Informasi Berbasis TOGAF ADM pada Dinas Pariwisata dan Kebudayaan Kota Yogyakarta. Seminar Nasional Aplikasi Teknologi Informasi (SNATI), 2012, pp 1-3.

[9] http://www.pubs.opengroup.org/ diakses Oktober 2016.

[10]Fahmi, Ian., Adam, Yuli., \& Rahmad, Basuki., Perancangan Enterprise Architecture Fungsi Marketing dan Layanan Pelanggan dengan Menggunakan Framework TOGAF ADM pada PT. Herona Express. 2016 